\title{
Gender gap in financial inclusion: Evidence from MENA
}

\author{
Ekin Ayşe Özşuca* \\ Department of International Trade, Çankaya University, Etimesgut, Turkey
}

Received: 8 April 2019

Accepted: 13 June 2019

\begin{abstract}
This study aims to analyze the gender dimension of financial inclusion in MENA countries. Using the World Bank's 2017 Global Findex Database, it explores the underlying factors of gender differences in formal financial services usage via Fairlie decomposition method. The findings of the study indicate that a significant portion of the disparity in financial inclusion is attributable to employment, while age and tertiary education are also found as contributing factors to the financial inclusion gap. Another notable finding is that upper income quintiles contribute positively to the gender gap, indeed to a greater extent compared to lower income groups.
\end{abstract}

Keywords: financial inclusion; financial services; gender; MENA

JEL Classification Codes: G21, O16

\section{Introduction}

International statistics highlight a marked gender disparity in the use of formal financial services among developing regions of the world, while gender gap in account ownership is recorded to be significantly highest in the MENA region with 17 percentage points. Suffering from civil wars, political conflicts, income stagnation, economic and financial instability over the years, improving access to financial services, especially for the underprivileged groups of the population like women and those in poverty, is at utmost importance for MENA countries in terms of creating jobs, stimulating investments, supporting economic growth, alleviating poverty, reducing income inequality and thereby, contributing to sustainable development. Accordingly, the pursuit of inclusive finance has become a recent policy focus for several countries in MENA (Pearce, 2011).

Despite the policy makers' increasing commitment for financial inclusion across much of the region, the empirical literature on financial inclusion that focuses on the MENA region is rather

\footnotetext{
*E-mail: aozsuca@cankaya.edu.tr.

Citation: Özşuca, E. A. (2019) Gender gap in financial inclusion: Evidence from MENA, Economics and Business Letters, 8(4), 199-208.
}

DOI: $10.17811 /$ ebl.8.4.2019.199-208 
scant. The previous literature mainly examines financial inclusion by concentrating on its relationship with poverty, inequality and financial stability (Neaime, 2018), or the impact of individual characteristics on financial inclusion indicators (Shihadeh, 2018), while no previous study has investigated the gender dimension of financial inclusion in the context of MENA countries yet. ${ }^{1}$ Therefore, this paper aims to fill this gap and, is, to the best of our knowledge, the first to explore the relationship between access to finance and gender on an individual level for MENA countries.

Against this background, the paper aims to contribute to the literature by analyzing the gender gap in financial inclusion for the MENA region, drawing upon non-linear decomposition techniques to examine contributing factors that explain variation in the use of formal financial services between men and women. Using the World Bank's Global Findex database for 2017, the empirical analysis consists of decomposing the gender differentials in financial inclusion via the Fairlie (1999) methodology for a large sample of MENA countries. The paper is organized as follows. Section 2 presents the empirical methods, while Section 3 explains the data employed in the study. Next is, Section 4 that discusses the estimation results. Finally, Section 5 provides concluding remarks.

\section{Methods}

To analyze the components of gender gap, the Fairlie non-linear decomposition method, which extends the standard Oaxaca-Blinder (1973) decomposition for logistic regression, is employed. In particular, this method allows causes of gender differences to be examined in a binary outcome, as is the case of our financial inclusion measures, in which a probit or logit model is estimated. This technique identifies the gap in the probability of an outcome between two subgroups and quantifies the contribution of group differences in the independent variables to the existing gap.

In line with Fairlie (1999), the decomposition for a nonlinear equation of the type $Y=$ $F(X \hat{\beta})$ can be stated as:

$$
\bar{Y}^{M}-\bar{Y}^{F}=\left[\sum_{i=1}^{N^{M}} \frac{F\left(X_{i}^{M} \widehat{\beta}^{M}\right)}{N_{M}}-\sum_{i=1}^{N^{F}} \frac{F\left(X_{i}^{F} \widehat{\beta}^{M}\right)}{N_{F}}\right]+\left[\sum_{i=1}^{N^{F}} \frac{F\left(X_{i}^{F} \widehat{\beta}^{M}\right)}{N_{F}}-\sum_{i=1}^{N^{F}} \frac{F\left(X_{i}^{F} \widehat{\beta}^{F}\right)}{N_{F}}\right]
$$

where $\bar{Y}^{J}$ is the average probability of the specific financial inclusion level, $\bar{X}^{J}$ is the set of average of independent variables, $\hat{\beta}^{J}$ is the coefficient estimates for gender $J(J=M, F$ for male and female, respectively). $N^{J}$ refers to the relative size of each group, while $F$ is the cumulative distribution function from standard normal distribution. The first component in brackets is the gender differential due to differences in the endowments of characteristics of the independent variables, whereas the second term corresponds to the differences in the returns to the exogenous covariates, but it also captures the gender gap resulting from differences in unmeasurable or unobserved endowments. This first component, which is also called as 'the explained part', is taken as reflecting an estimate of the contribution of gender differences in the entire set of independent variables to the gender gap in financial inclusion. Consequently, the contribution of each variable to the gender disparity can be assessed by considering the change in the average predicted probability from replacing male distribution with the female distribution, while holding the distributions of the other variables constant.

\footnotetext{
${ }^{1}$ For studies that examine the gender dimension of financial inclusion for other countries or regions, see DemirgucKunt et al. (2013), Aterido et al. (2013), Swamy (2014), Fanta and Mutsonziwa (2016), Ghosh and Vinod (2016), Botric and Broz (2017), among others.
} 
Following Fairlie (2017), the decomposition results are averaged across 1000 randomly drawn replicate samples, while randomizing the order of covariates in order to address path-dependency issue in the empirical analysis. Moreover, instead of logistic regression, a probit model is used to mitigate the potential problem of unobserved heterogeneity prevalent in cross-sectional data. $^{2}$

\section{Data}

The study utilizes the micro data obtained from the latest edition of the World Bank Global Findex database of Demirgüç-Kunt et al. (2018). This dataset covers financial inclusion information for the year 2017 for more than 150 countries across the globe, which makes up approximately 97 percent of the world's population. It is built by compiling nationally representative surveys of more than 150,000 adults and provides detailed information on how individuals access accounts, make and receive payments, use financial technology, save and borrow. The data selected for this study covers 14 countries in the MENA region, with a total of 18,217 observations. Specifically, countries included in the analysis are Algeria, Bahrain, the Arab Republic of Egypt, Islamic Republic of Iran, Iraq, Kuwait, Jordan, Lebanon, Libya, Morocco, Saudi Arabia, Tunisia, United Arab Emirates and West Bank and Gaza.

As the dependent variable of interest, three measures of financial inclusion are used to capture different dimensions of ownership and usage of formal financial services. Specifically, these indicators are account penetration at a financial institution (Account), formal saving (Saving) and formal borrowing (Borrow), which are constructed using the survey responses that indicate whether the individual had an account at a formal financial institution, whether the individual saved at a formal financial institution in the past 12 months, and whether the individual borrowed from a formal financial institution in the past 12 months, respectively.

Several individual characteristics are incorporated as explanatory variables which are thought to affect gender disparity in financial inclusion. Among these variables, age is incorporated because gender differences in financial services usage are likely to be higher for older ages. In this respect, three separate age categories as younger, working age and older, are considered, and three dummy variables (Young, Middle, Old) are created that indicate each age category. More specifically, the young sample includes respondents between 15-24 years of age, the working age sample includes the individuals aged 25-49 and the older population covers those aged 50 and above. Here, the reference category is 25-49 years of age. Instead of adopting the conventional wisdom in labor market analysis, the sub-samples are compromised in that way to allow for more evenly distributed respondents across each category following Botric and Broz (2017). As people in the workforce are more likely to be financially included, employment status (Emp) is utilized and given the women's low levels of participation in economic life, which is particularly the case for MENA, the extent of men involved in economic activities is likely to have an impact in explaining the gender gap in access and use of formal financial services. Moreover, the education level is included to the analysis through dummy variables indicating the degree of formal education completed, defined as secondary (Seduc) and tertiary $(T e d u c)$, while primary school graduates (Peduc) are the base category. Since the level of one's education increases his/her probability of being more financially literate and financially included, differences in educational attainments between men and women can explain the financial inclusion gap. Moreover, as an important determinant of financial inclusion, the income level is incorporated since higher levels of income raise the probability of having assets

\footnotetext{
${ }^{2}$ The robustness of these results has been checked by using pooled coefficient estimates. Additional estimations are performed with and without sample weights as well. In general, the results are very similar and consistent with those for the baseline models. For the sake of brevity, these estimation results are not reported.
} 
and thus, engenders higher probability of financial inclusion. Since women in the MENA region not only suffer from serious barriers to employment, but also face a significant wage discrimination even if they manage to enter the labor market, it is evident that men are more likely to have more opportunities for having higher levels of income. Accordingly, five dummy variables $\left(I n c_{-} 1, I n c \_2, I n c \_3, I n c \_4, I n c \_5\right)$ are specified for each income quintile that the respondent belongs to, while the dummy variable for the middle income quintile is omitted. Finally, country dummy variables that seek to capture the impact of differences in financial inclusion variables by gender across the countries are included. In this case, Saudi Arabia is identified as the base category. Detailed description of the variables are provided in Table 1.

Table 1. Description of Variables in the Empirical Analysis.

\begin{tabular}{|c|c|c|}
\hline Variable & Notation & Description \\
\hline Account ownership & Account & 1if the person has an account in a financial institution, 0 otherwise \\
\hline Formal savings & Saving & 1 if the person saved using an account at a financial institution, 0 otherwise \\
\hline Formal borrowing & Borrow & 1 if the person borrowed from a financial institution, 0 otherwise \\
\hline Male & Male & 1 if the person is male, 0 otherwise \\
\hline Female & Female & 1 if the person is female, 0 otherwise \\
\hline Young & Young & 1 if the person is between $15-24$ years of age, 0 otherwise \\
\hline Middle & Middle & 1 if the person is between $25-49$ years of age, 0 otherwise \\
\hline Older & Old & 1 if the person is older than 50 years of age, 0 otherwise \\
\hline Employment & Emp & 1 if the person is in the workforce, 0 otherwise \\
\hline Income quintile 1 & Inc_l 1 & 1 if income is in the first quintile (poorest $20 \%$ ), 0 otherwise \\
\hline Income quintile 2 & Inc_2 & 1 if income is in the second quintile (second $20 \%$ ), 0 otherwise \\
\hline Income quintile 3 & Inc_3 & 1 if income is in the third quintile (third $20 \%$ ), 0 otherwise \\
\hline Income quintile 4 & Inc_4 & 1 if income is in the fourth quintile (fourth $20 \%$ ), 0 otherwise \\
\hline Income quintile 5 & Inc_5 & 1 if income is in the fourth quintile (fifth $20 \%$ ), 0 otherwise \\
\hline Primary education & Peduc & 1 if the person completed primary education, 0 otherwise \\
\hline Secondary education & Seduc & 1 if the person completed secondary education, 0 otherwise \\
\hline Tertiary education & Teduc & 1 if the person completed secondary education, 0 otherwise \\
\hline Country & Country & 1 if the person is from a specific country, 0 otherwise \\
\hline
\end{tabular}

In order to provide an evident first step picture of gender gap in financial inclusion, Table 2 displays summary statistics by gender breakdown for each MENA country used in the empirical analysis for the three financial inclusion measures, i.e. account ownership, formal saving and formal borrowing. Moreover, the differences in sample means are tested and the results are presented for each country.

As illustrated in Table 2, financial inclusion indicators vary to a great extent across the countries in the sample, while women are less likely to have an account with a formal financial institution and exhibit lower levels of saving and borrowing in all of the countries. The only exception is Iran as regards to formal credit where women are more likely to borrow via formal means when compared to men. Furthermore, t-tests indicate that gender differences in account ownership are statistically significant at least on a 5 percent confidence level for all of the countries, except for Iraq. Concerning formal saving and formal borrowing, the differences between men and women are statistically significant in most countries, but no statistically significant difference in the usage of formal financial services is found for Iran, Iraq and Kuwait. Notable is the fact that there are considerable differences in sample averages between countries. In the case of account ownership, the highest gap is in Jordan, whereas differences in the usage of formal saving and formal credit are highest in Libya and Bahrain, respectively. On the other side, disparity between men and women are found to be the lowest in Iraq for all of the three 
financial inclusion measures, though t-tests being statistically insignificant. In order to account for these differences across nations, country dummy variables are incorporated into the empirical analysis as well.

Table 2. Summary statistics of financial inclusion indicators by gender, country level (\% of male and female respondents within the country)

\begin{tabular}{lcllllllll}
\hline \hline & \multicolumn{3}{c}{ Account ownership } & \multicolumn{3}{c}{ Formal saving } & \multicolumn{3}{c}{ Formal borrowing } \\
& Male & Female & T-test & Male & Female & T-test & Male & Female & T-test \\
\hline \hline Algeria & 0.625 & 0.361 & $0.264 * * *$ & 0.182 & 0.108 & $0.073 * *$ & 0.045 & 0.028 & 0.017 \\
Bahrain & 0.901 & 0.832 & $0.069 * * *$ & 0.367 & 0.319 & 0.048 & 0.271 & 0.144 & $0.126 * * *$ \\
Egypt & 0.405 & 0.333 & $0.072 * *$ & 0.081 & 0.036 & $0.045 * * *$ & 0.088 & 0.052 & $0.036 * *$ \\
Iran & 0.965 & 0.912 & $0.052 * * *$ & 0.298 & 0.273 & 0.024 & 0.284 & 0.296 & -0.011 \\
Iraq & 0.223 & 0.210 & 0.012 & 0.018 & 0.008 & 0.009 & 0.038 & 0.034 & 0.004 \\
Kuwait & 0.855 & 0.801 & $0.053 * *$ & 0.325 & 0.275 & 0.050 & 0.182 & 0.178 & 0.026 \\
Jordan & 0.595 & 0.284 & $0.311^{* * *}$ & 0.146 & 0.072 & $0.074 * * *$ & 0.210 & 0.139 & $0.072 * * *$ \\
Lebanon & 0.626 & 0.412 & $0.214 * * *$ & 0.284 & 0.193 & $0.091 * * *$ & 0.203 & 0.141 & $0.062 * * *$ \\
Libya & 0.771 & 0.656 & $0.116 * * *$ & 0.277 & 0.159 & $0.118 * * *$ & 0.065 & 0.020 & $0.045 * * *$ \\
Morocco & 0.472 & 0.196 & $0.277 * * *$ & 0.124 & 0.034 & $0.090^{* * *}$ & 0.042 & 0.018 & $0.024 * * *$ \\
Saudi Arabia & 0.824 & 0.606 & $0.217 * * *$ & 0.203 & 0.102 & $0.101 * * *$ & 0.174 & 0.055 & $0.119 * * *$ \\
Tunisia & 0.484 & 0.320 & $0.164 * * *$ & 0.255 & 0.165 & $0.090^{* * *}$ & 0.136 & 0.061 & $0.074 * * *$ \\
UAE & 0.934 & 0.781 & $0.152 * * *$ & 0.323 & 0.250 & $0.073 * *$ & 0.213 & 0.159 & $0.053 *$ \\
West & 0.443 & 0.219 & $0.224 * * *$ & 0.087 & 0.069 & 0.018 & 0.104 & 0.042 & $0.063 * * *$ \\
Bank\&Gaza & & & & & & & & & \\
\hline \hline
\end{tabular}

Note. $* * *, * * *$ denote statistical significance at $1 \%, 5 \%$ and $10 \%$ levels, respectively.

\section{Results}

Table 3 presents the results of the decomposition to identify the underlying causes of gender differences in financial inclusion, as measured by account ownership with a financial institution (Model I), formal saving (Model II) and formal borrowing (Model III). For all of the models, the results indicate a significant gender gap in financial inclusion, i.e. men are likely to have an account with a financial institution and exhibit higher formal saving and formal borrowing when compared to women. In particular, financial inclusion disparity is widest ( 25 percent) for account ownership, while it is smallest (5 percent) for the formal credit.

In terms of contributors to the gender gap in financial inclusion, the decompositions show that, depending on the financial inclusion indicator considered, the set of chosen variables jointly explain between the 41 and 60 percent of the gap. The largest contributor to the differential in financial inclusion is employment in all specifications. Specifically, employment explains 9 of the gap in account penetration, whereas its contribution increases to 20 and 30 percent for formal saving and formal borrowing respectively, indicating that labor market exclusion is significantly related to the usage of formal credit and saving. The results regarding employment is not surprising given the high rates of unemployment registered in the MENA region during the past few decades in addition to prevailing large gender disparity in access to employment (Livani, 2009) and women's limited participation in economic life as salient features of the region's labor market. In terms of account penetration, the findings regarding employment for the MENA countries are similar to that of Central and South Eastern Europe and Sub-Saharan Africa regions, since the fact that women are less likely to be employed explains a great portion of why they are less likely to have an account with a financial institution in these regions. 
Notably, tertiary education level accounts for 8 to 17 percent of the gender gap in the probability of being financially included. That is to say; differences in higher educational attainment between men and women are contributing factors to explain the existing gaps in all financial inclusion indicators, while they are least important for having an account at a financial institution. Consequently, tertiary education emerges as the second largest contributor to the gap in all of the specifications. On the contrary, secondary education variable is found to only be statistically significant for the first model; hence, it stands out as a relevant determinant for explaining the male/female gap in account ownership. This finding stands in sharp contrast to that of Aterido et al. (2013) for Sub-Saharan Africa and Botric and Broz (2017) for Central and South Eastern Europe, who find secondary education as a strong factor in explaining the differences in account ownership among different levels of educational attainments. In particular, secondary education explains the existence of the gap to a much greater extent than tertiary education for the Sub-Saharan sample, while tertiary education is not found as statistically significant when the total sample is considered in Central and South Eastern Europe countries. Overall, the results affirm the stark gender differentials in educational attainment levels in the MENA region, while the impact of secondary/tertiary education appears to be different than that of some other developing regions of the world, deserving attention in future research.

Being statistically significant for all specifications, gender differences in younger age groups explains nearly 2 percent of the gap in account ownership and formal saving, whilst its effect climbs to 6 percent for formal borrowing specification. On the other side, the decomposition results reveal that gender gap among the older population contribute to about 0.5 percent of the gender differences in having an account and having saved at a financial institution, but it has no statistically significant impact on explaining the gap in the case of formal borrowing. In the younger age category having a quite remarkable stronger effect, age is detected as a significant determinant of the existing financial inclusion gap, which may be the result of the drastically high youth unemployment rates in the region as contended by the ILO (2015). It could also be the case that social/family pressures for being a housewife and women's reproductive role tend to be stronger in the younger population. Comparing the results with that of Central and South Eastern Europe, one can notice a striking difference since younger age acts towards reducing the gender gap in account ownership in that region, which is contrary to the MENA case.

As regards to the impact of income, decompositions reveal that differences in income levels explain the gender gap on average to only a minimal extent. In the case of account ownership and formal saving, the lower income quintiles explain a quite small portion of the gap $(0.40$ percent to 0.90 percent), while higher end income distribution is found to be significant in explaining the gap to a slightly greater extent (2 percent to 6 percent). This result is in line with the findings of Botric and Broz (2017) for Central and South Eastern Europe. In the case of formal borrowing, only the highest income quintile is found to be a significant covariate in explaining the gap. Thus, traditional gender division of roles in the family structure, i.e. men being more financially included given their bread-earner role in the society, appears to be more evident for the higher end of income distribution. In this case, the relatively larger contribution of highest income quintile for explaining the gap in formal saving is also noteworthy. Finally, the country of residence also appears to be an important contributor to the gender gap in financial inclusion.

\section{Concluding remarks}

This study analyzes the gender dimension of financial inclusion in the MENA region. Utilizing the Fairlie method, it investigates which individual attributes are important contributors to the 
gender gap in financial inclusion, measured on the basis of account ownership, formal saving and formal borrowing. Overall, the results confirm the gender gap in financial inclusion varying across countries. Non-linear decompositions show that a considerable portion of the gender gap is indeed attributable to employment, while age and education, especially tertiary education, are also found to be significant in explaining the gap. Regarding the usage of all formal financial services, a significant explanation is at highest income quintile, while lower end of income distribution only explains the existing gaps in account ownership and formal saving.

The results of the study suggest the need for efforts to improve gender parity in the formal financial system through innovative products and processes in addition to further policy action considering equity purposes. By demonstrating the individual attributes that are deemed significant in explaining the gender gap in financial inclusion, the findings of the paper could provide useful insights for building policies to enhance the likelihood of financial inclusion, and thereby to promote economic empowerment among women or at least to reduce the financial access gap for hitherto excluded women in MENA. However, the existence of a gender gap in financial inclusion is only an insufficient indicator of the discrimination against women

Table 3. Non-linear decompositions of gender gap in financial inclusion.

\begin{tabular}{|c|c|c|c|}
\hline & $\begin{array}{l}\text { Model I } \\
\text { (account) }\end{array}$ & $\begin{array}{l}\text { Model II } \\
\text { (saving) }\end{array}$ & $\begin{array}{l}\text { Model III } \\
\text { (borrow) }\end{array}$ \\
\hline Male & 0.6365 & 0.2041 & 0.1295 \\
\hline Female & 0.3854 & 0.1091 & 0.0750 \\
\hline Male/female gap & 0.2511 & 0.0950 & 0.0545 \\
\hline \multicolumn{4}{|c|}{ Contribution to difference } \\
\hline \multirow[t]{3}{*}{ Young } & $0.0044 * * *$ & $0.0015^{* * *}$ & $0.0034 * * *$ \\
\hline & $(0.0005)$ & $(0.0005)$ & $(0.0006)$ \\
\hline & $1.75 \%$ & $1.58 \%$ & $6.24 \%$ \\
\hline \multirow[t]{3}{*}{ Older } & $0.0013 * * *$ & $0.0005^{* *}$ & $7.28 \mathrm{e}-06$ \\
\hline & $(0.0003)$ & $(0.0002)$ & $(0.0002)$ \\
\hline & $\% 0.52$ & $\% 0.53$ & $0.01 \%$ \\
\hline \multirow[t]{3}{*}{ Emp } & $0.0232 * * *$ & $0.0193 * * *$ & $0.0165 * * *$ \\
\hline & $(0.0054)$ & $(0.0042)$ & $(0.0038)$ \\
\hline & $9.24 \%$ & $20.32 \%$ & $30.28 \%$ \\
\hline \multirow[t]{3}{*}{ Inc_l 1} & $0.0022 * * *$ & $0.0007 *$ & 0.0003 \\
\hline & $(0.0004)$ & $(0.0004)$ & $(0.0003)$ \\
\hline & $0.88 \%$ & $0.74 \%$ & $0.55 \%$ \\
\hline \multirow[t]{3}{*}{ Inc_2 } & $0.0010 * * *$ & 0.0005 & 0.0003 \\
\hline & $(0.0003)$ & $(0.0003)$ & $(0.0002)$ \\
\hline & $0.40 \%$ & $0.53 \%$ & $0.55 \%$ \\
\hline \multirow[t]{3}{*}{ Inc_4 } & 0.0001 & -0.0001 & $8.31 \mathrm{e}-06$ \\
\hline & $(0.0001)$ & $(0.0002)$ & $(0.0001)$ \\
\hline & $0.04 \%$ & $-0.11 \%$ & $0.02 \%$ \\
\hline \multirow[t]{3}{*}{ Inc_5 } & $0.0045^{* * *}$ & $0.0052 * * *$ & $0.0008 * *$ \\
\hline & $(0.0007)$ & $(0.0008)$ & $(0.0004)$ \\
\hline & $1.79 \%$ & $5.47 \%$ & $1.47 \%$ \\
\hline \multirow[t]{3}{*}{ Seduc } & $0.0122 * * *$ & 0.0010 & 0.0011 \\
\hline & $(0.0013)$ & $(0.0006)$ & $(0.0009)$ \\
\hline & $4.86 \%$ & $1.05 \%$ & $2.02 \%$ \\
\hline \multirow[t]{3}{*}{ Teduc } & $0.0197 * * *$ & $0.0162 * * *$ & $0.0057 * * *$ \\
\hline & $(0.0014)$ & $(0.0014)$ & $(0.0013)$ \\
\hline & $7.85 \%$ & $17.05 \%$ & $10.46 \%$ \\
\hline \multirow[t]{3}{*}{ Algeria } & 0.0001 & -0.0002 & $0.0009 * *$ \\
\hline & $(0.0002)$ & $(0.0003)$ & $(0.0004)$ \\
\hline & $0.04 \%$ & $-0.21 \%$ & $1.65 \%$ \\
\hline Bahrain & $0.0025^{* * * *}$ & $0.0040 * * *$ & $0.0024 * * *$ \\
\hline
\end{tabular}




\begin{tabular}{|c|c|c|c|}
\hline & $(0.0007)$ & $(0.0006)$ & $(0.0007)$ \\
\hline & $1 \%$ & $4.21 \%$ & $4.40 \%$ \\
\hline \multirow[t]{3}{*}{ Egypt } & $-0.0028 * * *$ & -0.0005 & -0.0002 \\
\hline & $(0.0005)$ & $(0.0004)$ & $(0.0003)$ \\
\hline & $-1.12 \%$ & $-0.53 \%$ & $-0.37 \%$ \\
\hline \multirow[t]{3}{*}{ Iran } & -0.0007 & $-0.0017 * * *$ & $-0.0018 * * *$ \\
\hline & $(0.0005)$ & $(0.0005)$ & $(0.0005)$ \\
\hline & $-0.28 \%$ & $-1.79 \%$ & $-3.30 \%$ \\
\hline \multirow[t]{3}{*}{ Iraq } & $-0.0105 * * *$ & $-0.0023 * * *$ & $-0.0012 * *$ \\
\hline & $(0.0007)$ & $(0.0004)$ & $(0.0005)$ \\
\hline & $-4.18 \%$ & $-2.42 \%$ & $-2.20 \%$ \\
\hline \multirow[t]{3}{*}{ Kuwait } & $0.0037 * * *$ & 0.0006 & $-0.0022 * * *$ \\
\hline & $(0.0007)$ & $(0.0006)$ & $(0.0008)$ \\
\hline & $1.47 \%$ & $0.63 \%$ & $-4.04 \%$ \\
\hline \multirow[t]{3}{*}{ Jordan } & 0.0001 & $0.0037 * * *$ & -0.0002 \\
\hline & $(0.0010)$ & $(0.0009)$ & $(0.0006)$ \\
\hline & $0.04 \%$ & $3.89 \%$ & $-0.37 \%$ \\
\hline \multirow[t]{3}{*}{ Lebanon } & 0.0007 & $-0.0012 * * *$ & -0.0005 \\
\hline & $(0.0002)$ & $(0.0004)$ & $(0.0003)$ \\
\hline & $0.28 \%$ & $-1.26 \%$ & $-0.92 \%$ \\
\hline \multirow[t]{3}{*}{ Libya } & $-0.0039 * * *$ & $0.0017 * *$ & $-0.0024 * * *$ \\
\hline & $(0.0010)$ & $(0.0008)$ & $(0.0006)$ \\
\hline & $-1.55 \%$ & $1.79 \%$ & $-4.40 \%$ \\
\hline \multirow[t]{3}{*}{ Morocco } & $0.0313 * * *$ & 0.0025 & $0.0075^{* * *}$ \\
\hline & $(0.0028)$ & $(0.0017)$ & $(0.0014)$ \\
\hline & $12.47 \%$ & $2.63 \%$ & $13.76 \%$ \\
\hline \multirow[t]{3}{*}{ Tunisia } & $0.0024 * * *$ & $-0.0016 * * *$ & 0.0002 \\
\hline & $(0.0004)$ & $(0.0005)$ & $(0.0004)$ \\
\hline & $0.96 \%$ & $-1.68 \%$ & $0.37 \%$ \\
\hline \multirow[t]{3}{*}{$U A E$} & $0.0032 * * *$ & $0.0037 * * *$ & 0.0008 \\
\hline & $(0.0008)$ & $(0.0011)$ & $(0.0010)$ \\
\hline & $1.27 \%$ & $3.89 \%$ & $1.47 \%$ \\
\hline \multirow[t]{3}{*}{ West Bank\&Gaza } & $0.0083 * * *$ & $0.0020 * * *$ & $0.0011^{*}$ \\
\hline & $(0.0008)$ & $(0.0006)$ & $(0.0006)$ \\
\hline & $3.31 \%$ & $2.11 \%$ & $2.02 \%$ \\
\hline \multirow{2}{*}{ Total explained } & 0.1025 & 0.0554 & 0.0325 \\
\hline & $40.82 \%$ & $58.32 \%$ & $59.63 \%$ \\
\hline
\end{tabular}

Notes. $* * * * * * *$ denote statistical significance at $1 \%, 5 \%$ and $10 \%$ levels, respectively.

in the formal financial system, as women are disadvantaged in many other grounds in the MENA region and that the main distressing concern is in fact that the underrepresentation of women in the modern market economy, in terms of labor market participation and education. Accordingly, it is evident that besides increasing labor market participation of women and their access to jobs with better pay and work conditions, policies aimed at promoting entrepreneurship among women, endorsing their job market-related skills, supporting schooling rates of girls in all educational levels, improving educational quality, enhancing youth employment are of particular importance for reducing the financial inclusion gap. The results of the study further suggest that it would be more beneficial for policy makers to design countryspecific policies and produce effective tools for addressing gender disparity in the MENA region.

\section{References}

Aterido, R., Beck, T., and Iacovone, L. (2013) Gender and Finance in Sub-Saharan Africa: Is There a Gender Gap?, World Development, 47, 102-120. 
Blinder, A. S. (1973) Wage Discrimination: Reduced Form and Structural Estimates, Journal of Human Resources, 8, 436-455.

Botric, V., and Broz, T. (2017) Gender Differences In Financial Inclusion: Central and South Eastern Europe, South-Eastern Europe Journal of Economics, 15(2), 209-227.

Demirguc-Kunt, A., Klapper, L., and Singer, D. (2013) Financial Inclusion and Legal Discrimination Against Women: Evidence From Developing Countries, World Bank Policy Research Working Paper, ref.6416.

Demirguc-Kunt, A., Klapper, L., Singer, D., Ansar, S., and Hess, J. R. (2018) The Global Findex Database 2017: Measuring Financial Inclusion and the Fintech Revolution, Washington, DC: World Bank.

Fairlie, R. W. (1999) The Absence of the African-American Owned Business: An Analysis of the Dynamics of Self-Employment, Journal of Labor Economics, 17(1), 80-108.

Fairlie, R. W. (2017) Addressing Path Dependence and Incorporating Sample Weights in theNonlinear Blinder-Oaxaca Decomposition for Logit, Probit and Other Nonlinear Models, SIEPR Discussion Paper, No. 17-013.

Fanta, A. B., and Mutsonziwa, K. (2016) Gender and Financial Inclusion: Analysis of Financial Inclusion of Women in the SADC Region, Policy Research Paper, No. 01/2016.

Ghosh, S. and Vinod, D. (2017) What Constrains Financial Inclusion for Women? Evidence from Indian Micro Data, World Development, 92, 60-81.

ILO (2015) Global Employment Trends for Youth 2015: Scaling Up Investments in Decent Jobs for Youth, International Labour Office: Geneva.

Livani, T. (2009) The Status and Progress of Women in the Middle East and North Africa, Washington, DC: World Bank Group.

Neaime, S., and Gaysset, I. (2018) Financial Inclusion and Stability in MENA: Evidence from Poverty and Inequality, Finance Research Letters, 24, 230-237.

Oaxaca, R. L. (1973) Male-Female Wage Differentials in Urban Labor Markets, International Economic Review, 14, 693-709.

Pearce D. (2011) Financial Inclusion in the Middle East and North Africa: Analysis and Roadmap Recommendations, World Bank Policy Research Working Paper 5610.

Shihadeh, F. H. (2018) How Individual's Characteristics Influence Financial Inclusion: Evidence from MENAP, International Journal of Islamic and Middle Eastern Finance and Management, 11(4), 553-574.

Swamy, V. (2014) Financial Inclusion, Gender Dimension, and Economic Impact on Poor Households, World Development, 56, 1-15. 


\section{Appendix A}

Table A. Probit regression models of Fairlie decompositions.

\begin{tabular}{|c|c|c|c|}
\hline & $\begin{array}{l}\text { Model I } \\
\text { (Account) }\end{array}$ & $\begin{array}{l}\text { Model II } \\
\text { (Saving) }\end{array}$ & $\begin{array}{l}\text { Model III } \\
\text { (Borrow) }\end{array}$ \\
\hline Constant & $\begin{array}{l}0.3563 * * * \\
(0.0866)\end{array}$ & $\begin{array}{l}-1.5603 * * * \\
(0.0926)\end{array}$ & $\begin{array}{l}-1.4008 * * * \\
(0.1012)\end{array}$ \\
\hline Young & $\begin{array}{l}-0.6626 * * * \\
(0.0433)\end{array}$ & $\begin{array}{l}-0.1457 * * * \\
(0.0505)\end{array}$ & $\begin{array}{l}-0.5585^{* * * *} \\
(0.0639)\end{array}$ \\
\hline Older & $\begin{array}{l}0.2638 * * * \\
(0.0399)\end{array}$ & $\begin{array}{l}0.1228 * * * \\
(0.0412)\end{array}$ & $\begin{array}{l}0.0032 \\
(0.0455)\end{array}$ \\
\hline Emp & $\begin{array}{l}0.1707 * * * \\
(0.0395)\end{array}$ & $\begin{array}{l}0.2076 * * * \\
(0.0471)\end{array}$ & $\begin{array}{l}0.2236 * * * \\
(0.0550)\end{array}$ \\
\hline Inc_l & $\begin{array}{l}-0.3961 * * * \\
(0.0506)\end{array}$ & $\begin{array}{l}-0.3018 * * * \\
(0.0597)\end{array}$ & $\begin{array}{l}-0.1967 * * * \\
(0.0632)\end{array}$ \\
\hline Inc_2 & $\begin{array}{l}-0.1954 * * * \\
(0.0497)\end{array}$ & $\begin{array}{l}-0.0863 \\
(0.0554)\end{array}$ & $\begin{array}{l}-0.0953 \\
(0.0601)\end{array}$ \\
\hline Inc_4 & $\begin{array}{l}0.1122 * * \\
(0.0478)\end{array}$ & $\begin{array}{l}0.1154 * * \\
(0.0502)\end{array}$ & $\begin{array}{l}-0.0679 \\
(0.0547)\end{array}$ \\
\hline Inc_5 & $\begin{array}{l}0.3452 * * * \\
(0.0470)\end{array}$ & $\begin{array}{l}0.4463 * * * \\
(0.0467)\end{array}$ & $\begin{array}{l}0.1148 * * \\
(0.0547)\end{array}$ \\
\hline Seduc & $\begin{array}{l}0.4648 * * * \\
(0.0388)\end{array}$ & $\begin{array}{l}0.2955 * * * \\
(0.0485)\end{array}$ & $\begin{array}{l}0.3185^{* * * *} \\
(0.0542)\end{array}$ \\
\hline Teduc & $\begin{array}{l}0.9843 * * * \\
(0.0513)\end{array}$ & $\begin{array}{l}0.7030 * * * \\
(0.0532)\end{array}$ & $\begin{array}{l}0.3919 * * * \\
(0.0605)\end{array}$ \\
\hline Algeria & $\begin{array}{l}-0.4036^{* * * *} \\
(0.0876)\end{array}$ & $\begin{array}{l}0.0988 \\
(0.0907)\end{array}$ & $\begin{array}{l}-0.6331 * * * \\
(0.1181)\end{array}$ \\
\hline Bahrain & $\begin{array}{l}0.3399 * * * \\
(0.0938)\end{array}$ & $\begin{array}{l}0.5225 * * * \\
(0.0771)\end{array}$ & $\begin{array}{l}0.3112 * * * \\
(0.0793)\end{array}$ \\
\hline Egypt & $\begin{array}{l}-1.1089 * * * \\
(0.0846)\end{array}$ & $\begin{array}{l}-0.4461 * * * \\
(0.1004)\end{array}$ & $\begin{array}{l}-0.2929 * * * \\
(0.0977)\end{array}$ \\
\hline Iran & $\begin{array}{l}0.9778 * * * \\
(0.1332)\end{array}$ & $\begin{array}{l}0.3209 * * * \\
(0.0864)\end{array}$ & $\begin{array}{l}0.4207 * * * \\
(0.0872)\end{array}$ \\
\hline $\operatorname{Iraq}$ & $\begin{array}{l}-1.6098 * * * \\
(0.0852)\end{array}$ & $\begin{array}{l}-1.1307 * * * \\
(0.1332)\end{array}$ & $\begin{array}{l}-0.7110^{* * * *} \\
(0.1111)\end{array}$ \\
\hline Kuwait & $\begin{array}{l}-0.5117 * * * \\
(0.0918)\end{array}$ & $\begin{array}{l}-0.1071 \\
(0.1008)\end{array}$ & $\begin{array}{l}0.2943 * * * \\
(0.0950)\end{array}$ \\
\hline Jordan & $\begin{array}{l}0.0016 \\
(0.0879)\end{array}$ & $\begin{array}{l}0.3509 * * * \\
(0.0860)\end{array}$ & $\begin{array}{l}-0.0288 \\
(0.0819)\end{array}$ \\
\hline Lebanon & $\begin{array}{l}-0.5913 * * * \\
(0.0880)\end{array}$ & $\begin{array}{l}0.3659 * * * \\
(0.0860)\end{array}$ & $\begin{array}{l}0.1822 * * \\
(0.0894)\end{array}$ \\
\hline Libya & $\begin{array}{l}-0.3207 * * * \\
(0.0833)\end{array}$ & $\begin{array}{l}0.1712^{* *} \\
(0.0781)\end{array}$ & $\begin{array}{l}-0.5843 * * * \\
(0.0950)\end{array}$ \\
\hline Morocco & $\begin{array}{l}-0.7557 * * * \\
(0.0719)\end{array}$ & $\begin{array}{l}-0.1087 \\
(0.0729)\end{array}$ & $\begin{array}{l}-0.5916^{* * * *} \\
(0.0825)\end{array}$ \\
\hline Tunisia & $\begin{array}{l}-0.8608 * * * \\
(0.0879)\end{array}$ & $\begin{array}{l}0.3573 * * * \\
(0.0887)\end{array}$ & $\begin{array}{l}-0.0457 \\
(0.0968)\end{array}$ \\
\hline$U A E$ & $\begin{array}{l}0.4096 * * * \\
(0.0994)\end{array}$ & $\begin{array}{l}0.2734 * * * \\
(0.0766)\end{array}$ & $\begin{array}{l}0.0683 \\
(0.0799)\end{array}$ \\
\hline West Bank\&Gaza & $\begin{array}{l}-0.9882 * * * \\
(0.0921)\end{array}$ & $\begin{array}{l}-0.4257 * * * \\
(0.1110)\end{array}$ & $\begin{array}{l}-0.1876^{*} \\
(0.1066)\end{array}$ \\
\hline Observations & 9504 & 9472 & 9480 \\
\hline Decomposition obs. & 18217 & 18155 & 18172 \\
\hline Pseudo R2 & 0.2806 & 0.1450 & 0.1170 \\
\hline Log likelihood & -4481.2398 & -4097.869 & -3227.1245 \\
\hline
\end{tabular}

Notes. Standard errors are presented in parentheses. $* * *, * * *$ denote statistical significance at $1 \%, 5 \%$ and $10 \%$ levels, respectively. 